\title{
The Garden City Now A Tattered City: Effects And Ethical Implications Of Poor Waste Management In Port Harcourt, Rivers State.
}

\author{
Big-Alabo Sotonye \\ Department of Philosophy, University of Port Harcourt Rivers State, Nigeria. \\ Email address: sotonzopapaz@gmail.com \\ Contact: +2348064226401
}

\begin{abstract}
The issue of poor waste management has become a very important issue of concern to various scholars in environmental studies. Effective waste management in Port Harcourt has been seen as one of the greatest issue being faced in Rivers State. It cannot be over emphasized that the generation of waste and its adverse effect has increased overtime. This paper critically looks into the ethical implications and effects of poor waste management in Rivers state with focus on Port Harcourt. Hence, this paper was able to establish that the failure of the government to enact environmental laws and punishing those found wanting and also providing the necessary working tools for waste managers have all resulted to poor waste management. Thus, the effects of all these cannot be over emphasized. This paper makes some significant recommendations for government, waste managers and the public in general on the necessity to adopt certain ethical principles and also to sensitize the populace on proper waste management. The paper in conclusion exposes some ethical implications and effects of poor waste management in Port Harcourt and how it has resulted to the city of Port Harcourt called the Garden City now been seen as a Tattered City.
\end{abstract}

Keywords: Waste Management, Port Harcourt, Garden city, Virtue ethics, Land ethic and Environment.

\section{$\underline{\text { Introduction }}$}

Rivers state is one of the 36 states in Nigeria and is said to have 23 local governments in which Port Harcourt the capital of the state is one of its 23 local governments. Port Harcourt is said to be the garden city of Nigeria. This slogan 'Garden City' is as a result of the greenness of the environment. The name Port Harcourt was given by the then colonial master Sir Fredrick Luggard in honor of Lewis Vernon Harcourt, the then secretary of state for the colonies. This was done after the port was built within 1912 and 1913. History has it that after crude was found at Olobiri in 1956, it was through Port Harcourt that the first shipload of crude was exported out of the country in 1958. Port Harcourt, the administrative and commercial capital of oil rich Rivers state is seen or said to be the Garden City of Nigeria as this is as a result of its richness in greenery. As at 2016, the Port Harcourt Urban area is said to have estimated a population of about 1,865,000 inhabitants rising from the previous estimate of about 1,382,592 in the year $2006 .{ }^{1}$

The increase in population over the decades in the city of Port Harcourt have resulted to issues that relates to population explosion or increase. In this work the issue that will be keenly looked at is the issue of poor waste management in Port Harcourt city the capital of Rivers State. ${ }^{1}$

Waste can be seen as a substance that is said to have no further use and requires on-site or off-site treatment and disposal. Hence, waste can take any form which could be solid, liquid or gas and each have 
separate methods or ways of disposal and management. Consequently, waste management are the activities and actions that are required to manage waste from its start point or inception to its final disposal, hence, when these waste are not properly managed it thus does have a boomerang effect or impact on the environment. These effect could be seen with respect to poor waste management in Port Harcourt, Rivers state. Waste management is intended to minimize adverse effects of waste on health and also on the environment.

\section{Waste Management}

Waste management is a procedure that precludes the collection, transportation and recycling or disposal of waste. It covers management, processes and resources that see to adequate handling of waste production. The management of these resources requires servicing of the waste transportation trucks and the disposal equipment so that they can adhere to the environmental directives and also health codes. The main purpose of waste management is to by all means refrain from or avoid the adverse effects of wastes on human health and the environment. Obviously, in most cases, companies in charge of waste management carryout the process to get useful resources. These waste materials can be in various forms of matters, which include liquid form, gaseous form, solid form and radioactive form of matter.

As stated by waste management companies, there are various or so many methods of waste management. All methods varies from one geographical area to another and also vary from industrial and residential areas. Nevertheless, it is clear that management of waste is ordinarily the duty of the local government. The methods or process of waste management requires proper dumping, collection, transportation and the creation of awareness.

\section{Methods of Waste Management}

a) Dumping method: this is the most common type of waste dumping methods which includes landfill and incineration. Landfill simply means burying of wastes in a common pit. Whereas incineration means combustion of waste materials.

b) Recycling method: this method is useful mostly to waste materials that are said to be organic in nature.

c) Collection and transportation: this process of waste depends on the place. In some places the usage of waste disposal bin is preferred and they differ in sizes and prices.

d) Creation of Awareness: creating awareness is very important for the persistence of the security of the humankind and global health. ${ }^{1}$

\section{$\underline{\text { Literature Review }}$}

Proper waste management has turned out to be one of a noteworthy worry in ecological issues ${ }^{2}$. This is especially consistent with urban regions where populace is quickly developing and amount of waste produced is expanding more than ever ${ }^{3}$. Current earth's populace is 6.8 billion and it is evaluated that half of this populace lives in urban regions (Population Division of the Department of Economic and Social Affairs of the United Nations Secretariat, 2009). Waste generation increase relatively to this populace number and income, making the requirements of a successful administration ${ }^{2}$. Urbanization and 


\section{GIS Business}

industrialization prompts new ways of life and conduct which likewise influences waste composition from primarily organic to manufactured materials that last longer, for example, plastics and other bundling material ${ }^{4}$. E-waste that scarcely existed before was produced as much as $20-50$ metric tons a year (UNEP, 2006).

The management of waste turned out to be complex and the offices furnished can't adapt to the expanding request and needs. Accordingly, best methodology should be executed quickly while thinking about ecological, social and economic viewpoints ${ }^{5}$. The drivers of sustainable waste management were illuminated by ${ }^{6}$, which incorporate human, economic, institutional and ecological perspective.

The waste management framework ought to be dynamic and constantly dependent on new bits of knowledge and encounters ${ }^{7}$. For instance, persistent appraisal of current approach and regulatory system of New Zealand demonstrated the absence of strategies coordination, harmful waste management, consistency, motivating forces and markets for reused material, and cleaner production exertion ${ }^{8}$. Subsequently, the enhancement in policy is required while it will likewise profit the nation. For instance, based from EU25 gathering, it was discovered that the generation of waste is expanding and is anticipated upon to proceed for a long time ahead. After the enactment of the new EU's strategy in waste recovery and incineration, the measure of waste landfilled has been diminishing gradually ${ }^{2}$. Notwithstanding, based from the information or data from developed nations, the actual measure of waste been landfilled is really diminishing as more waste are burned, treated the soil or reused. Taking a gander at the positive point, Lomborg trusted that region required is adequate to cater the aggregate sum of waste generated by the world, yet the issue is the area since no one needs to remain close landfills ${ }^{9}$. He additionally reported that air from incinerators and groundwater close to landfills today are cleaner and more secure.

Taking a gander at the waste generation pattern of developed nation, it is believed that other changed and developing nations will encountered the same. As of not long ago, the generation of waste is expanding and it is believed to keep rising. This is an issue of worry for experts everywhere throughout the world. It is believed that the quantity of waste will keep on heaping up the landfill and some time or another the land won't have the capacity to get any longer waste.

\section{Effects of poor waste management in Port Harcourt}

Looking at the issues of poor waste management in Port Harcourt one can obviously point out the adverse effects this problem has brought to the populace at large. The following can be seen as the effects of poor waste management:

a) Environmental effects.

b) Health effects.

c) Economic effects.

d) Social effects.

a) Environmental effects: man undoubtedly is part and parcel of the environment. The environment and everything in it is what sustains man. The environmental effects of poor waste management in Port Harcourt include waste pollution i.e. waste from disposal sites through flooding as a result of land degradation and blocked drainages. The pollution of waste results to serious problems for 


\section{GIS Business}

both humans and animals. These effects also amounts to the depletion of the ozone layer too. This effect is not only limited to the disposal site but it does cut across the surrounding or area where the waste is been generated, spread or accumulated. Consequently, its only when a waste is properly managed that its effects can be controlled or else its effects will continue until it has fully decomposed or otherwise stabilized. Another effect pointed out is air pollution i.e. pollution from smoke, noise, odour, dust etc. consequently, research has it that poorly managed waste brings about environmental hazard in Port Harcourt city ${ }^{10}$.

b) Health effects: it is important to note that the health effects of poorly managed waste are numerous on man. These effects comes in various forms of sickness such as irritation of the throat/nose, convulsion, chest pains, vomiting, blood disorder, skin burns, anemia, lung cancer and even death. It is certain that it is the environmental effects that lead to the health effects. Thus, other health effects from poor waste management include injuries from razor blades, glass, syringes, and infections through respiration, ingestion or skin contact. However, research has it that poorly managed waste in Port Harcourt brings about these health problems as pointed out earlier. ${ }^{10}$

c) Economic effects: the economic effects are obviously because one cannot do business in an environment that is dirty. Hence, people that do businesses around areas where you have waste usually end up losing their customers or get poor patronage due to the refuse around the business area. The customers usually complain of the smell because they cannot withstand it so therefore will have to look for somewhere else where they can purchase the goods that they need. Consequently, such areas are been affected economically because businesses do not do well around such areas. ${ }^{10}$

d) Social effects: clearly, there are various stories of social effects on people or persons that are domicile or close to waste dumpsite. One of such effects is that persons that stay around such areas are seen as dirty people even when some are actually not dirty. Another effect is that most persons that leave around such areas find it difficult to bring or invite some of their friends to their houses in other not to be looked down on as being dirty. ${ }^{10}$

\section{Ethical Implications of Poor Waste Management in Port Harcourt}

In looking at the ethical implications of poor waste management in Port Harcourt we used the Land Ethic and Environmental virtue ethics as a framework to guide and analyze the ethical implications of poor waste management in Port Harcourt.

\section{The Land Ethic}

Aldo Leopold as one of the Vanguards of environmental ethics formulated the land ethic in the 1940s. Aldo Leopold in his book A Sand County Almanac posited 'All ethics so far evolved rest upon a single premise; that the individual is a member of a community of inter dependent parts. His instincts prompt him to compete for his place in that community, but his ethics prompt him also to cooperate' ${ }^{11}$. In other words the Land Ethic clearly points out that human beings ought to see themselves as a member of a wider community, i.e. the biotic community which includes both living things and all other members of the ecological systems ${ }^{12}$. For Leopold, 'the land ethic simply enlarges the boundaries of the community

to include soils, waters, plants and animals, or collectively: the land' ${ }^{11}$. For him environmental ethics can 


\section{GIS Business}

be defined as follows: 'A thing is right when it tends to preserve the integrity, stability and beauty of the biotic community. It is wrong when it tends otherwise ${ }^{12}$. According to him the Land Ethic distorts the role of Homo sapiens from conqueror of the land community to just a normal or ordinary member. In other words, this simply implies a necessary respect for not only his fellow members but also for the community at large ${ }^{11}$. The source of Land Ethic is ecology, which is the science of interrelationships amongst organisms and their environment.

Consequently, looking at Leopold's Land Ethic we will sense some emphasis on conservation and respect for the entirety of the community. Hence, he saw preservation as 'a state of harmony between men and Land' ${ }^{11}$. Furthermore, looking at the central message of his Land Ethic, we can actually see a connection with the definition of environmental ethics in it.

In summary, linking or applying his concept of Land Ethic to poor waste management in Port Harcourt we will see that the waste managers and the government have not done enough to solve this problem of poor waste management. From the point at which residents dispose their waste we would find out that their reckless attitude of waste disposal makes the work very difficult for the waste managers and these reckless acts have resulted to many environmental issues such as pollution, blocked drainages which also have resulted to flooding in some areas. Also the waste managers have failed too on their side. This is because they do not provide enough equipment for their jobs and then the few they have are not properly maintained for full usage. Furthermore, the government also to a large extent have failed in providing finance frequently for the waste managers to carry out their duty and also the sensitization and enforcement of environmental laws have not been carried out properly. Looking at all these actions from Leopold's central thesis in his Land Ethic, we can conclude that all these acts do not tend to preserve the integrity, stability and beauty of the environs of Port Harcourt city and therefore can be termed as wrong.

\section{Environmental Virtue Ethics}

Aristotle was a pupil of Plato for about two decades. He was born in Stageira in 384BC. His main works on ethics include the famous Nicomachean Ethics and Magna Moralia. One of the central idea in his ethics states clearly that all human actions are directed towards the attainment of certain ends. In other words, all human actions is a means to an end which for him is seen as good. Thus some ends are sought only as means to further ends and not as ends in themselves ${ }^{13}$.

Consequently, happiness for Aristotle is the only end which is not a means to an end. Hence, all ends are sought just because they lead to pursue this end which does not lead to any other end. This end is the ultimate end which is happiness. According to him, the only way to attain happiness is through morality. This means that happiness is the purpose and standard of morality. Hence, the view that sees happiness as the parameter or yardstick of morality is known as eudemonism. Aristotle went further to define happiness as 'the activity of the soul in accordance with virtue'. In other words happiness as an activity of the soul is inseparable from virtue ${ }^{13}$.

Obviously, it will be absurd to talk about Aristotle Ethics without looking at the concept of virtue. According to him there are two types of virtue namely, intellectual virtue and moral virtue. Examples of intellectual virtue for Aristotle are sound deliberation, art, practical wisdom, intuitive reasoning and example of moral virtues are temperance, courage, justice, generosity etc. ${ }^{13}$. Aristotle is said to have taught the doctrine of golden mean which possess that virtue lies between two extremes. Virtue according to him, comes from habit. It is more like an internal disposition, a permanent state of mind inclined 


\section{GIS Business}

towards good actions which spring spontaneously from it. Consequently, virtue is the state of mind which spontaneously gives rise to good actions as a matter of habit ${ }^{13}$. When one does a good action it does not mean the person is a virtuous person, it only means so when the action is spontaneous but when it is not spontaneous but done once in a while it therefore means that the actor is not a virtuous person. In other words a good action is performed as a result of habit. In this light, Aristotle pointed or emphasized on the importance of acquiring good habits from the beginning "it makes no small difference therefore, whether we are habituated in one way or in another from youth upwards; indeed, makes a very great difference, nay, all the differences", 13

Practical wisdom as an important notion in Aristotle's ethics is the rule or standard by which any given action in any given situation can be judged as right or wrong. It is innate in virtuous persons making them to ascertain what is right or wrong at any given moment. Clearly, it is only a virtuous man that can be a man of practical wisdom and he gets this through experience ${ }^{13}$.

The main question for virtue ethics is "what sort of person should I become? ". Virtue ethics looks at those traits of character that makes one a good person and it seeks to promote distinguished individuals who will act well out of a spontaneous goodness which inspire others. The moral life thus is a matter of trying to ascertain the type of people we are supposed to be and of attending to the development of character within our communities and ourselves. Obviously, understanding of the traditional virtue ethics has set the pace for understanding environmental virtue ethics. Hence, specifying norms of character is what constitutes environmental virtue ethics. It is pertinent to understand that we must have to develop the right attitude and dispositions in our relationship with the environment. Furthermore, the environmentally virtuous person is disposed to respond both emotionally and through action to the environment in an excellent or fine way.

Sandler sees environmental virtue as follows:

Environmental virtue is not merely instrumentally valuable in itself. It is life affirming and life enhancing. Those who possess it are better off than those who do not, for they are able to find reward, satisfaction and comfort from their relationship with nature; and it is their character, their capacity to appreciate, respect and love nature that opens them to these benefits. To those who are receptive to it, nature is a source of joy, peace, renewal and self-knowledge ${ }^{14}$.

In conclusion, it is obvious that the emphasis here is the concept of virtue. If doing what is good is habitual or comes spontaneously from a person it therefore means the individual possesses practical wisdom because he or she is a virtuous person. Hence this individual knows what to do when he is faced with issues of two extremes. Consequently, applying this to poor waste management, we will clearly see or understand that if everyone involved in the process of waste, that is from the point of generation to the point of management are virtuous persons, then the managers, the government and everyone involved will not have a problem in doing the right thing so as to help in waste management. From the point of waste generation, which is basically from household waste, it is expected that the residents of Port Harcourt City are supposed to abide by the environmental which makes us to understand that household waste should be 
bagged properly and dumped at government designated areas and at appointed time where the waste managers will come pick them up to do the needful. Nevertheless, because most residents lack virtue they do not abide by these environmental laws and as a result, waste is been disposed inappropriately thereby making Port Harcourt city to look tattered. Furthermore, investigations also make us to understand that most times the waste managers and government do not work in synergy. This is mostly because the government fails most times in providing moneys or the finance these waste managers need to make their work a successful one. This means the government has also failed in its side of the contract and this is usually linked to corrupt practices and mismanagements of these funds. This only happens when those involved lack virtue.

\section{Conclusion}

In current day Port Harcourt City, the attitude of the populace towards waste generation and waste disposal has resulted to a serious damage to the human ecosystem. The attitude of humans towards waste generation and its disposal obviously have a negative effect on the human health and sanity. This work made us to understand that the populace of Port Harcourt city were not conscious of the implications of poor waste management which had resulted to the poor nature and de facing of the environment known as the Garden City. Consequently, since environmental studies and enlightenment can change human attitude towards the environment which includes waste management and its disposal, it is thus the responsibility of the government, agencies, waste managers and everyone involved in the process of waste to ensure effective waste management and disposal in other to avoid its boomerang effect.

\section{Reference}

1. Kio.L, Dekor J.B (2014). Port Harcourt, the Garden City: A Garden of Residents Nightmare. World Environment, 4(3): 111-120, DOI:10.5923/j.env.20140403.03.

2. Mazzanti, M. and R. Zoboli (2008). "Waste generation, waste disposal and policy effectiveness: Evidence on decoupling from the European Union.” Resource, Conservation, Recycling, 52, $1221-1234$

3. Kathiravale S, Muhd Yunus MN (2008). "Waste to wealth.” Asia Europe Journal, 6(2), 359-371.

4. Idris A, Inanc B and Hassan MN (2004) Overview of waste disposal and landfills/dumps in Asian countries. Journal of Materials Cycles and Waste Management 6: 104-110.

5. Aye, L., Widjaya, E.R (2006). "Environmental and economic analyses of waste disposal options for traditional markets in Indonesia”, Waste Management, 26, 1180 - 1191. 
6. Agamuthu, P., Fauziah, S. H., Kahlil, K. (2009). "Evolution of solid waste management in Malaysia: impacts and implications of the Solid Waste Bill", Journal of Material Cycles and Waste Management, 11, 96-103.

7. Arnold van de Klundert. (1999). "Integrated Sustainable Waste Management: the selection of appropriate technologies and the design of sustainable systems is not (only) a technical issue," CEDARE/IETC Inter-Regional Workshop on Technologies for Sustainable Waste Management, held Alexandria, Egypt 13-15 July 1999

${ }^{8 .}$ Boyle, C.A. (2000). Solid waste management in New Zealand. Waste Management 20(7): 517-526

9. Lomborg, The skeptical environmentalist on 22 September 1998, Lomborg published the Danish book verdens sande, 1998.

${ }^{10}$. Ogunmakinde. O.E (2013). Effects of Poor Waste Management on Highways: A Case Study of AbujaKeffi Expressway.

${ }^{11 .}$ Leopold, Aldo, 1886-1948. (1949). A Sand County almanac, and Sketches here and there. (C1949.

12. Olen, J., \& Barry, V. (2002). Environmental Ethics. In Applying Ethics. Belmont, CA: Wadsworth.

13. Omoregbe. J (2012). Ethics: A Systematic and Historical Study. Joja Publishers: Lagos.

14. Sandler, Ronald, and Philip Cafaro (2005). Environmental Virtue Ethics. Lanham: Rowman \& Littlefield. 